\title{
Synthesis and properties of pyrimidine-containing linear molecules
}

\author{
Ken-Tsung Wong,* Yun-Ruei Lu and Yuan-Li Liao \\ Department of Chemistry, National Taiwan University, Taipei 106, Taiwan \\ Received 24 April 2001; revised 13 July 2001; accepted 17 July 2001
}

\begin{abstract}
Palladium-catalyzed Stille and Sonogashira coupling reactions were sequentially applied for constructing novel pyrimidine-containing linear molecules. The chemoselectivity of 5-bromo-2-iodopyrimidine (1) towards Pd-catalyzed coupling reaction serves as a tool for the successful control of the arrangement of dipolar pyrimidine moieties inside the conjugated backbone. The influence of the arrangement of dipolar pyrimidine in the linear backbone on their absorption and photoluminescence are not stupendous. Thermogravimetric analysis (TGA) indicate that all linear molecules in this study exhibit high thermal stability. (C) 2001 Elsevier Science Ltd. All rights reserved.
\end{abstract}

Rigid and rod-like molecules with extended $\pi$-conjugation are of interest due to their potential use in nanoscale electronics, e.g. molecular wires. ${ }^{1}$ Modifications of the primary properties of these well-defined linear systems have been achieved by introducing a functional moiety as a conjugated subunit or as a terminal group. For example, better electron delocalization along the molecular axis can be achieved by introducing a redoxactive transition metal as the central linkage. ${ }^{2}$ The introduction of a photoactive moiety into the $\pi$-conjugated skeleton has also been found to perform a switch function. ${ }^{3}$ Heteroaromatics with potential coordinating ability have also been introduced as a part of the conjugated backbone ${ }^{4}$ or as terminal groups. ${ }^{5}$ In this paper, we report the synthesis of linear molecules containing pyrimidine subunits in the conjugated backbone of the molecule. Due to the high electron affinity, ${ }^{6}$ the presence of the pyrimidine moiety in a $\pi$-conjugated system could create a new class of compounds with high electron accessibility. Alternatively, control on the arrangement of the dipolar pyrimidine moiety in a defined $\pi$-conjugated system could serve as an additional tool for tuning the physical properties.

Under mild conditions, Pd-catalyzed coupling reactions of 5-bromo-2-iodopyrimidine (1) with arylboronic acids $^{7}$ (Suzuki coupling) or terminal alkynes ${ }^{7,8}$ (Sonogashira reaction) have been found to proceed chemose-

\footnotetext{
Keywords: pyrimidine; molecular wire; Sonogashira coupling.

* Corresponding author. Tel.: +886-2-2363-0231 ext. 3315; fax: +886-

2-2363-6359; e-mail: kenwong@ccms.ntu.edu.tw
}

lectively at the $\mathrm{C} 2$ position. The bromo substituent at the $\mathrm{C} 5$ position remains intact, allowing a consecutive coupling reaction with either arylboronic acids or terminal alkynes, using the same Pd-catalyst. ${ }^{8}$ Therefore, the dipolar orientation of the pyrimidine group in a linear conjugated system can be controlled by taking advantage of the difference in reactivity at $\mathrm{C} 2$ and $\mathrm{C} 5$ positions of 1 . In our previous report, ${ }^{8}$ we have shown that the photophysical properties of a $\pi$-conjugated system with alternating triple bonds and aromatic rings were found to be irrespective of the difference in arrangement of the dipolar pyrimidine moiety. And, the molecules prefer to have a coplanar conformation in the ground state due to the lack of ortho-ortho steric interactions between the two aromatic rings, which are separated by a triple bond. However, in the case of a conjugated molecule containing a pyrimidine group attached to the phenyl ring, the physical properties could depend on the different arrangement of the pyrimidine unit in the backbone.

Compound 3 was obtained by the Pd-catalyzed coupling of the pyrimidine derivative 1 with metallo-compounds of the type 2 , in which the trimethylsilylethynyl group serves as a masked reaction site for the further extension of $\pi$-conjugation. Compounds of the type 2 with different metallo substituents were tested for their coupling efficiency with $\mathbf{1}$ in the presence of various Pd-catalysts (cf. Table 1). Reaction of compound 1 with $2(\mathrm{M}=\mathrm{ZnCl})$ in the presence of $\mathrm{PdCl}_{2}(\mathrm{dppf})$ or $\mathrm{PdCl}_{2}\left(\mathrm{PPh}_{3}\right)_{2}$ as catalyst (entries 1 and 2, Table 1) resulted in the recovery of 1 . Treating 1 with $2(M=$ $\mathrm{MgBr}$ ) in the presence of a catalytic amount of 
Table 1. Pd-catalyzed coupling reactions of $\mathbf{1}$ with metallo compound $\mathbf{2}$

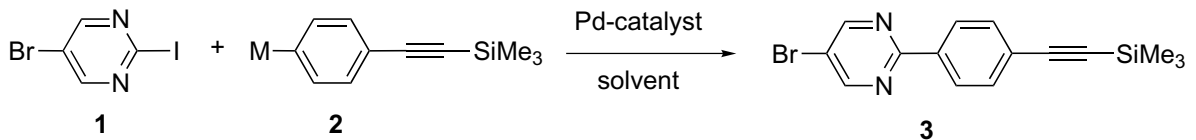

\begin{tabular}{|c|c|c|c|c|}
\hline Entry & $2(\mathrm{M}=)$ & Pd-catalyst & Solvent (temperature, ${ }^{\circ} \mathrm{C}^{\mathrm{a}}$ ) & 3 Yield $(\%)^{\mathrm{b}}$ \\
\hline 1 & $\mathrm{ZnCl}$ & $\mathrm{PdCl}_{2}(\mathrm{dppf})$ & THF (80) & 0 \\
\hline 2 & $\mathrm{ZnCl}$ & $\mathrm{PdCl}_{2}\left(\mathrm{PPh}_{3}\right)_{2}$ & THF (80) & 0 \\
\hline 4 & $\mathrm{SnBu}_{3}$ & $\mathrm{PdCl}_{2}\left(\mathrm{PPh}_{3}\right)_{2}$ & DMF (160) & 48 \\
\hline 5 & $\mathrm{SnBu}_{3}$ & $\mathrm{PdCl}_{2}\left(\mathrm{PPh}_{3}\right)_{2} / \mathrm{Ag}_{2} \mathrm{O}$ & DMF (160) & 23 \\
\hline 6 & $\mathrm{SnBu}_{3}$ & $\mathrm{Pd}\left(\mathrm{PPh}_{3}\right)_{4}$ & DMF (160) & 6 \\
\hline
\end{tabular}

${ }^{\text {a }}$ Temperature of oil bath.

${ }^{\mathrm{b}}$ Isolated yield.

$\mathrm{PdCl}_{2}\left(\mathrm{PPh}_{3}\right)_{2}$ in refluxing THF led to the formation of 3 , but in a very low yield (3\%, entry 3 , Table 1$)$. In DMF, Sn-derivative $2\left(\mathrm{M}=\mathrm{SnBu}_{3}\right)$ coupled with $\mathbf{1}$ more efficiently in the presence of $\mathrm{PdCl}_{2}\left(\mathrm{PPh}_{3}\right)_{2}$ to afford 3 in $48 \%$ yield. However, by changing the catalyst system from $\mathrm{PdCl}_{2}\left(\mathrm{PPh}_{3}\right)_{2}$ to $\mathrm{Pd}\left(\mathrm{PPh}_{3}\right)_{4}$ or by carrying out the reaction in the presence of $\mathrm{Ag}_{2} \mathrm{O},{ }^{9}$ the yields of 3 were found to be further reduced (entries 5 and 6 , Table 1). Finally, it was found that by changing the reaction solvent from DMF to toluene, the yield of 3 could be increased to $63 \%$. The lack of ortho-ortho interactions between the pyrimidine ring and the phenyl ring could be beneficial for increasing the conjugation length of 3 in the ground state.

The conjugation length of $\mathbf{3}$ was extended by a Sonogashira coupling reaction by treating 3 with the dialkyne $4 \mathbf{a}$ or $\mathbf{4 b}$ in the presence of ${ }^{i} \mathrm{Pr}_{2} \mathrm{NH}$ and catalytic amounts of $\mathrm{Pd}\left(\mathrm{PPh}_{3}\right)_{4}$ and $\mathrm{CuI}$ in refluxing $\mathrm{THF}^{10}$ to yield the linear compounds $\mathbf{5 a}$ and $\mathbf{5 b}$ in 71 and $68 \%$, respectively (Scheme 1). Changing the orientation of the pyrimidine group in $\mathbf{5}$ could be achieved by treating the dialkyne $\mathbf{4}$ with $\mathbf{1}$ to afford $\mathbf{6},{ }^{8}$ followed by a Stille coupling reaction with $2\left(\mathrm{M}=\mathrm{SnBu}_{3}\right)$ in the presence of $\mathrm{PdCl}_{2}\left(\mathrm{PPh}_{3}\right)_{2}$. Accordingly, the linear molecules $7 \mathbf{a}$ and $\mathbf{7 b}$, which have the same $\pi$-conjugated backbone as that of $\mathbf{5 a}$ and $\mathbf{5 b}$ but with a different arrangement of the pyrimidine moieties were isolated in 48 and $45 \%$ yield, respectively. However, due to the ortho-ortho interaction between the pyrimidine ring and the phenyl ring in $\mathbf{7 a}$ and $\mathbf{7 b}$ could result in a noncoplanar conformation in the ground state. The terminal trimethylsilylethynyl groups in $\mathbf{5 a}$ and $\mathbf{5 b}$, as well as in $7 \mathbf{a}$ and $7 \mathbf{b}$ can be removed by standard desilylation procedures, resulting in the formation of new reaction sites, which provide the possibilty for further modifying the end groups of the linear molecules $5 \mathbf{a}, \mathbf{5 b}, 7 \mathbf{a}$ and $7 \mathrm{~b}$.

Another approach towards increasing the conjugation length was achieved by treating $\mathbf{3}$ with alkyne $\mathbf{8}$ using a Sonogashira coupling reaction to obtain 9 in $65 \%$ yield. The trimethylsilyl group in $\mathbf{9}$ was cleaved in the pres- ence of $2 \mathrm{~N} \mathrm{NaOH}$ in $\mathrm{MeOH} / \mathrm{THF}$ (3:1) at room temperature to afford compound $\mathbf{1 0}$ in $77 \%$ yield. The Sonogashira coupling procedure used for the synthesis of $\mathbf{1 2}$ resulted in complex products, hence the procedure was slightly modified to obtain $\mathbf{1 2}$. Thus, three equal portions of $\mathbf{1 0}$ in THF was added every $4 \mathrm{~h}$ to the refluxing THF solution of the diiodo compound 11 in the presence of $\mathrm{Pd}\left(\mathrm{PPh}_{3}\right)_{4}, \mathrm{CuI}$ and ${ }^{i} \mathrm{Pr}_{2} \mathrm{NH}$ to yield $\mathbf{1 2}$ $(45 \%) .{ }^{11}$ From the above facts, it is evident that the conjugation length as well as the arrangement of the dipolar pyrimidine moieties in the conjugated backbone could be manipulated by employing different reaction sequences.

Optical absorption and photoluminescence studies were carried out on the pyrimidine-containing molecules 5a, $\mathbf{5 b}, \mathbf{7 a}, \mathbf{7 b}$, and $\mathbf{1 2}$ (cf. Table 2). Due to the electrondonating property, the introduction of the dioctyloxy side chains leads to a significant red-shift in the electronic absorption and the emission maxima compared to that of the linear molecules with dioctyl side chains $(\mathbf{5} \mathbf{a}$ versus $\mathbf{5 b}$ and $\mathbf{7 a}$ versus $\mathbf{7 b}$ ). The compounds $\mathbf{5 a}, \mathbf{5 b}$, $\mathbf{7 a}, 7 \mathbf{b}$, and 12 show very intense blue fluoresence with high quantum yields upon irradiation at their absorption maxima. Dilute solutions of $\mathbf{5 b}$ and $\mathbf{7 b}$ in EtOAc and $\mathrm{CHCl}_{3}$, exhibit similar absorption and emission spectra irrespective of the difference in the dipolar orientation of the pyrimidine moiety in the backbone. However, 5a and 7a show different emission maxima in EtOAc. Especially, dilute solution of $7 \mathbf{a}$ in EtOAc shows solvatochromic behavior with an emission maximum at $389 \mathrm{~nm}$ and a shoulder at $409 \mathrm{~nm}$. In $\mathrm{CHCl}_{3}$ the emission maximum of $7 \mathbf{a}$ is red shifted to $402 \mathrm{~nm}$ with a shoulder at $423 \mathrm{~nm}$. But, in $\mathrm{CHCl}_{3}$, the difference in the emission maxima of $\mathbf{5 a}$ and $7 \mathbf{a}$ is less than that in EtOAc. Interestingly, $\mathbf{5 b}, \mathbf{7 b}$, and $\mathbf{1 2}$ show a similar behavior in their absorption and emission maxima. Based on the structure, one would expect 12 to have a longer conjugation length compared with those of $\mathbf{5 b}$ and $\mathbf{7 b}$; however, the photophysical studies indicate that the $\pi$-conjugation of $\mathbf{1 2}$ along the molecular axis is 'saturated' and not longer than that of $\mathbf{5 b}$ and $7 b$. 
<smiles>CC#Cc1ccc(-c2ncc(Br)cn2)cc1</smiles><smiles>[R]c1cc(C#N)c([R])cc1C#C</smiles>

$\mathrm{iPr}_{2} \mathrm{NH}, \mathrm{THF}, 80^{\circ} \mathrm{C}$ $\mathrm{Me}_{3} \mathrm{Si}$

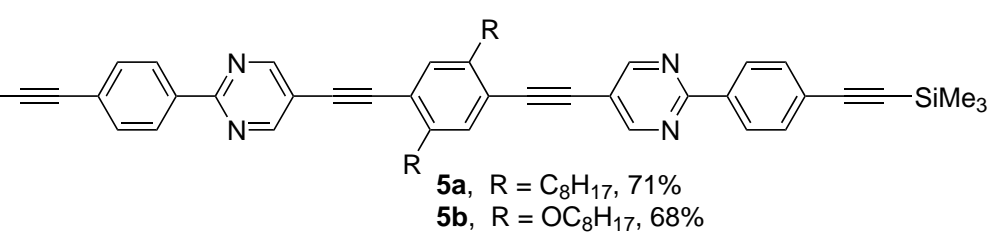<smiles>[R]c1cc(C#C)c([R])cc1C#C</smiles><smiles>[R]c1cc(C#Cc2ncc(Br)cn2)c([R])cc1C#Cc1ncc(Br)cn1</smiles>

6a, $\mathrm{R}=\mathrm{C}_{8} \mathrm{H}_{17}$ 6b, $\mathrm{R}=\mathrm{OC}_{8} \mathrm{H}_{17}$<smiles>[R]c1cc(C#Cc2ncc(-c3ccc(C#C[SiH2]C)cc3)cn2)c([R])cc1C#Cc1ncc(-c2ccc(C#C[SiH2]C)cc2)cn1</smiles>

7a, $\mathrm{R}=\mathrm{C}_{8} \mathrm{H}_{17}, 46 \%$

$7 \mathrm{~b}, \mathrm{R}=\mathrm{OC}_{8} \mathrm{H}_{17}, 41 \%$<smiles>CC#Cc1ccc(-c2ncc(Br)cn2)cc1</smiles><smiles>C#Cc1ccc(C(C)(C)C)cc1</smiles><smiles>C[SiH2]C#Cc1ccc(-c2ncc(C#Cc3ccc(C(C)(C)C)cc3)cn2)cc1</smiles>
$\mathrm{iPr}_{2} \mathrm{NH}, \mathrm{THF}, 80^{\circ} \mathrm{C}$

$65 \%$

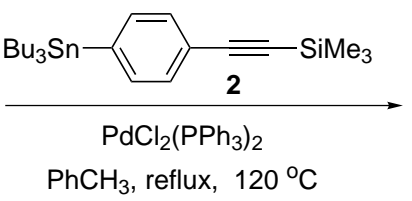

$\mathrm{PhCH}_{3}$, reflux, $120^{\circ} \mathrm{C}$
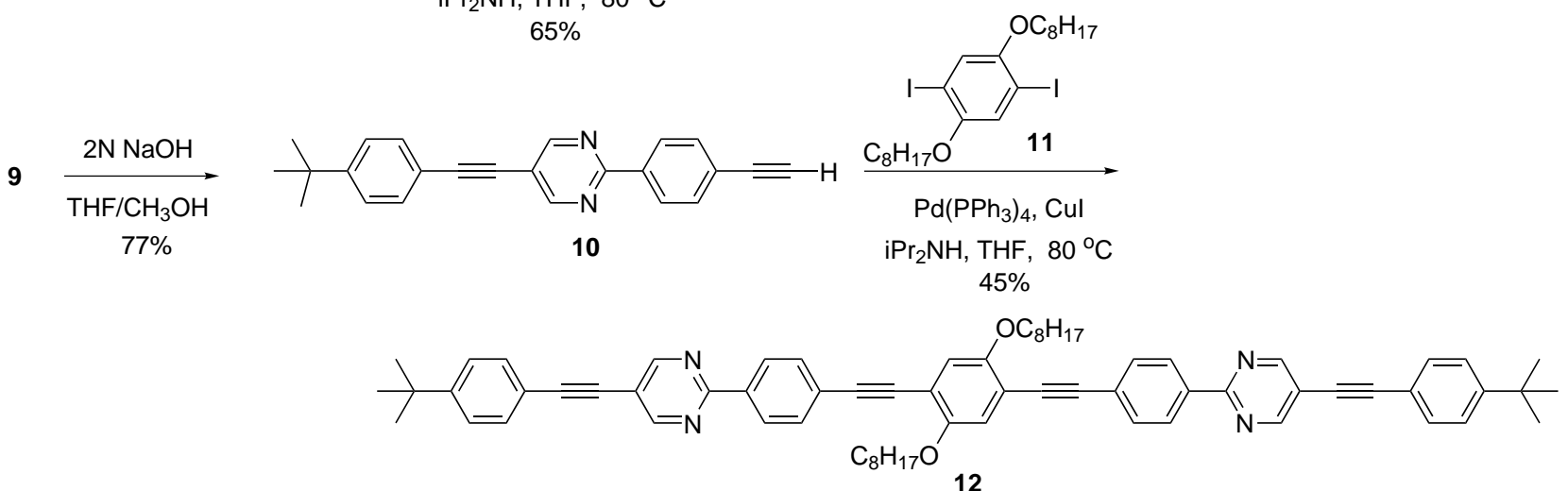

\section{Scheme 1.}

Table 2. Physical properties of pyrimidine-containing linear molecules $5 \mathbf{a}, \mathbf{5 b}, \mathbf{7 a}, \mathbf{7 b}$, and $\mathbf{1 2}$

\begin{tabular}{lllllc}
\hline Compound & $\lambda_{\max }(\mathrm{nm})$ in EtOAc & $\lambda_{\mathrm{em}}(\mathrm{nm})$ in EtOAc & $\lambda_{\mathrm{em}}(\mathrm{nm})$ in $\mathrm{CHCl}_{3}$ & ${\text { Quantum yield }(\%)^{\mathrm{a}}}^{T_{\mathrm{d}}\left({ }^{\circ} \mathrm{C}\right)^{\mathrm{b}}}$ \\
\hline $\mathbf{5 a}$ & 362 & 398,421 & 407,427 & 87 & 359,459 \\
$\mathbf{5 b}$ & 332,394 & $449^{\mathrm{c}}$ & 449 & 62 & 348,434 \\
$\mathbf{7 a}$ & 357 & 389,409 & 402,423 & 67 & 467 \\
$\mathbf{7 b}$ & 331,396 & $454^{\mathrm{c}}$ & 454 & 35 & 308,423 \\
$\mathbf{1 2}$ & 387 & 450 & 455 & 372,426 \\
\hline
\end{tabular}

${ }^{a}$ In EtOAc, Coumarin I was employed as standard.

${ }^{\mathrm{b}}$ Detected by TGA.

${ }^{\mathrm{c}}$ The excitation spectra of $\mathbf{5 b}$ and $\mathbf{7 b}$ are similar to their absorption spectra, the emission spectra were recorded upon excitation at 394 nm for $\mathbf{5 b}$ and $396 \mathrm{~nm}$ for $\mathbf{7 b}$. 
Thermal stability of $\mathbf{5 a}, \mathbf{5 b}, \mathbf{7 a}, \mathbf{7 b}$ and $\mathbf{1 2}$ was investigated by TGA. No decomposition was observed below $300^{\circ} \mathrm{C}$, and the decomposition temperatures $\left(T_{\mathrm{d}}\right)$ are summarized in Table 2. The TG thermograms reveal that complete weight loss occurs before $500^{\circ} \mathrm{C}$, which corresponds to the removal of the alkyl or alkoxy side chains. The residue is stable without any further decomposition up to $800^{\circ} \mathrm{C}$. The high thermal stability of the residue could be attributed to the thermal crosslinking of the conjugated backbone.

In summary, we have established an efficient pathway for introducing the highly electronegative pyrimidine moiety into a $\pi$-conjugated backbone affording a new class of linear molecules. Control on the dipolar orientation of pyrimidine in the conjugated backbone was accomplished by taking advantage of the different reactivities at the $\mathrm{C} 2$ and $\mathrm{C} 5$ position of $\mathbf{1}$. However, the photophysical studies indicate that the difference in the arrangement of the pyrimidine moiety in the $\pi$-conjugated system has a slight influence on their properties.

\section{Acknowledgements}

This work was supported by the National Science Council of Taiwan (NSC-88-2113-M002-036, NSC-892113-M002-008). We thank Professor Hsiu-Fu Hsu and Dr. Jörn Wirsching for their suggestive discussion on the preparation of the manuscript.

\section{References}

1. (a) Petty, M. C.; Bryce, M. R.; Bllor, D. Introduction to Molecular Electronics; Edward Arnold, 1995; (b) Tour, J. M. Acc. Chem. Res. 2000, 33, 791-804.

2. (a) Wong, K.-T.; Lehn, J.-M.; Peng, S.-M.; Lee, G.-H. Chem. Commun. 2000, 2259-2260; (b) Jones, N. D.; Wolf, M. O. Organometallics 1997, 16, 1352-1354; (c) Collbert, M. C. B.; Lewis, J.; Long, N. J.; Raithby, P. R.; White, A. J. P.; Williams, D. J. J. Chem. Soc., Dalton Trans. 1997, 99-104; (d) Lebreton, C.; Touchard, D.; Pichon, L. L.; Dairdor, A.; Toupet, L.; Dixneuf, P. H. Inorg. Chim. Acta 1998, 272, 188-196.

3. (a) Marsella, M. J.; Wang, Z.-Q.; Mitchell, R. H. Org. Lett. 2000, 2, 2979-2982; (b) Matsuda, K.; Irie, M. J. Am. Chem.
Soc. 2000, 122, 7195-7201; (c) Fernandez-Acebes, A.; Lehn, J.-M. Chem. Eur. J. 1999, 5, 3285-3292.

4. Khatyr, A.; Ziessel, R. J. Org. Chem. 2000, 65, 7814-7824.

5. Harriman, A.; Ziessel, R. Chem. Commun. 1996, 17071716.

6. (a) Gammper, R.; Mari, H.-J.; Polborn, K. Synthesis 1997, 696-718; (b) Kanbara, T.; Kushida, T.; Saito, N.; Kuwajima, I.; Kubota, K.; Yamamoto, T. Chem. Lett. 1992, 583-586.

7. Goodby, J. W.; Hird, M. H.; Lewis, R. A.; Toyne, K. J. Chem. Commun. 1996, 2719-2720.

8. Wong, K.-T.; Hsu, C. C. Org. Lett. 2001, 3, 173-175.

9. Malm, J.; Björk, P.; Gronowitz, S.; Hörnfeldt, A.-B. Tetrahedron Lett. 1992, 33, 2199-2202.

10. An improved procedure for Sonagashira coupling: Thorand, S.; Krause, N. J. Org. Chem. 1998, 63, 855-8553.

11. New compounds were characterized by spectroscopic techniques. Selected data: Compound 3: ${ }^{1} \mathrm{H} \mathrm{NMR}\left(\mathrm{CDCl}_{3}, 400\right.$ $\mathrm{MHz}) \delta 8.83(\mathrm{~s}, 2 \mathrm{H}), 8.35(\mathrm{~d}, J=8.8 \mathrm{~Hz}, 2 \mathrm{H}), 7.51(\mathrm{~d}$, $J=8.8 \mathrm{~Hz}, 2 \mathrm{H}), 0.27(\mathrm{~s}, 9 \mathrm{H})$, Anal. calcd for $\mathrm{C}_{15} \mathrm{H}_{15} \mathrm{BrN}_{2} \mathrm{Si}$ : C, 54.38; H, 4.56; N, 8.46, found: C, 54.23; H, 4.65; N, 8.41. Compound 5a: ${ }^{1} \mathrm{H} \mathrm{NMR}\left(\mathrm{CDCl}_{3}, 400 \mathrm{MHz}\right) \delta 8.90(\mathrm{~s}, 4 \mathrm{H})$, $8.42(\mathrm{~d}, J=7.4 \mathrm{~Hz}, 4 \mathrm{H}), 7.60(\mathrm{~d}, J=7.4 \mathrm{~Hz}, 4 \mathrm{H}), 7.43$ (s, $2 \mathrm{H}), 2.83(\mathrm{t}, J=7.6 \mathrm{~Hz}, 4 \mathrm{H}), 1.52-1.55(\mathrm{~m}, 4 \mathrm{H}), 1.29-1.33$ $(\mathrm{m}, 20 \mathrm{H}), 0.87-0.89(\mathrm{~m}, 6 \mathrm{H}), 0.28$ (s, 9H); Anal. calcd for $\mathrm{C}_{56} \mathrm{H}_{66} \mathrm{~N}_{4} \mathrm{Si}_{2}$ : C, 79.01; H, 7.81; N, 6.58, found: C, 78.90; $\mathrm{H}, 7.68 ; \mathrm{N}, 6.63$. Compound 5b: ${ }^{1} \mathrm{H}$ NMR $\left(\mathrm{CDCl}_{3}, 400\right.$ $\mathrm{MHz}) \delta 8.90(\mathrm{~s}, 4 \mathrm{H}), 8.40(\mathrm{~d}, J=8 \mathrm{~Hz}, 4 \mathrm{H}), 7.60(\mathrm{~d}, J=8$ $\mathrm{Hz}, 4 \mathrm{H}), 7.06(\mathrm{~s}, 2 \mathrm{H}), 4.06(\mathrm{t}, J=6.6 \mathrm{~Hz}, 4 \mathrm{H}), 1.92-1.95$ $(\mathrm{m}, 4 \mathrm{H}), 1.29-1.33(\mathrm{~m}, 20 \mathrm{H}), 0.87-0.90(\mathrm{~m}, 6 \mathrm{H}), 0.28(\mathrm{~s}$, $9 \mathrm{H}$ ); Anal. calcd for $\mathrm{C}_{56} \mathrm{H}_{66} \mathrm{~N}_{4} \mathrm{O}_{2} \mathrm{Si}_{2}: \mathrm{C}, 76.14 ; \mathrm{H}, 7.53 ; \mathrm{N}$, 6.34, found: C, 75.93; H, 7.55; N, 6.38. Compound 7a: $\delta$ 8.97 (s, 4H), $7.62(\mathrm{~d}, J=8.6 \mathrm{~Hz}, 4 \mathrm{H}), 7.57$ (d, $J=8.6 \mathrm{~Hz}$, 4H), 7.57 (s, 2H), $2.91(\mathrm{t}, J=7.5 \mathrm{~Hz}, 4 \mathrm{H}), 1.73(\mathrm{~m}, 4 \mathrm{H})$, 1.25-1.41 (m, 20H), 0.84-0.87 (m, 6H), 0.28 (s, 9H); Anal. calcd for $\mathrm{C}_{56} \mathrm{H}_{66} \mathrm{~N}_{4} \mathrm{Si}_{2}: \mathrm{C}, 79.01 ; \mathrm{H}, 7.81 ; \mathrm{N}, 6.58$, found: $\mathrm{C}$, 79.30; H, 7.98; N, 6.53. Compound 7b: ${ }^{1} \mathrm{H}$ NMR $\left(\mathrm{CDCl}_{3}, 400 \mathrm{MHz}\right) \delta 8.95(\mathrm{~s}, 4 \mathrm{H}), 7.61(\mathrm{~d}, J=6.5 \mathrm{~Hz}, 4 \mathrm{H})$, $7.56(\mathrm{~d}, J=6.5 \mathrm{~Hz}, 4 \mathrm{H}), 7.17(\mathrm{~s}, 2 \mathrm{H}), 4.04(\mathrm{t}, J=6.7 \mathrm{~Hz}$, $4 \mathrm{H}), 1.84-1.88(\mathrm{~m}, 4 \mathrm{H}), 1.26-1.35(\mathrm{~m}, 20 \mathrm{H}), 0.87-0.87(\mathrm{~m}$, $6 \mathrm{H}), 0.27$ (s, 9H); Anal. calcd for $\mathrm{C}_{56} \mathrm{H}_{66} \mathrm{~N}_{4} \mathrm{O}_{2} \mathrm{Si}_{2}$ : C, 76.14; $\mathrm{H}, 7.53$; N, 6.34, found: C, 76.03; H, 7.65; N, 6.48. Compound 12: ${ }^{1} \mathrm{H} \mathrm{NMR}\left(\mathrm{CDCl}_{3}, 400 \mathrm{MHz}\right) \delta 8.90(\mathrm{~s}, 4 \mathrm{H})$, $8.46(\mathrm{~d}, J=8.0 \mathrm{~Hz}, 4 \mathrm{H}), 7.67$ (d, $J=8.0 \mathrm{~Hz}, 4 \mathrm{H}), 7.52$ (d, $J=8.4 \mathrm{~Hz}, 4 \mathrm{H}), 7.42(\mathrm{~d}, J=8.4 \mathrm{~Hz}, 4 \mathrm{H}), 7.05(\mathrm{~s}, 2 \mathrm{H}), 4.07$ $(\mathrm{t}, J=6.2 \mathrm{~Hz}, 4 \mathrm{H}), 1.92-1.95(\mathrm{~m}, 4 \mathrm{H}), 1.29-1.33(\mathrm{~m}, 20 \mathrm{H})$, 0.87-0.90 (m, 6H); Anal. calcd for $\mathrm{C}_{70} \mathrm{H}_{74} \mathrm{~N}_{4} \mathrm{O}_{2}$ : C, 83.79; H, 7.43; N, 5.58, found: C, 83.67; H, 7.25; N, 5.33. 